$\mathbf{R}_{\text {ESEARCh }} \mathbf{P}_{\text {APER }} \longrightarrow$ FOOD SCIENCE

\title{
Development of value added fruit jams
}

\author{
Asha Arya, Anuradha Doke, Jaishree G. Bhalerao and Rupali S. Shinde
}

Fruits can be preserved by preparing jam, jelly, squash, candy, etc. Among all these preparations jam is one in which maximum pulp of fruit is used. Jams are one of the most popular food products because of their low cost, all year long availability and organoleptic properties. Hence, an attempt was made to develop value added fruit jams. Amala and apple jam prepared with incorporation of nutritious ingredients (beet root powder, deoiled soya meal powder (DOSM), milk powder and watermelon powder) were evaluated to find out the most suitable and highly accepted level of incorporation. The most accepted products were assessed for their nutrient content and were stored to evaluate the shelf-life. The organoleptic evaluation indicated that value added amala and apple jam prepared with incorporation of beet root powder, milk powder, watermelon powder and de-oiled soya meal power at the levels of 1, 8,6,5 per cent and 1, 12, 12 and 9 per cent, respectively were significantly higher over the other variations. Due to value addition there was increase in protein $(5.85 \mathrm{~g} / 100 \mathrm{~g})$, total minerals $(0.71 \mathrm{~g} / 100 \mathrm{~g})$, calcium $(111.5 \mathrm{mg} / 100 \mathrm{~g})$, iron $(7.93 \mathrm{mg} / 100 \mathrm{~g})$ and zinc $(1.37 \mathrm{mg} / 100 \mathrm{~g})$ content of amala jam. The incorporation of nutrient rich ingredients to apple jam was helpful in increasing its nutrient content significantly. There was increase in protein $(10.36 \mathrm{~g} / 100 \mathrm{~g})$, total minerals $(1.35 \mathrm{~g} / 100 \mathrm{~g})$, fibre $(0.49 \mathrm{~g} / 100 \mathrm{~g})$ calcium $(175.73$ $\mathrm{mg} / 100 \mathrm{~g})$, iron $(16.68 \mathrm{mg} / 100 \mathrm{~g})$ and zinc $(3.57 \mathrm{mg} / 100 \mathrm{~g})$ content of apple jam. It is concluded that nutrient content can be increased by incorporating nutritious ingredient in both the jams.

Key Words : Jam, Beetroot powder, Deoiled soya meal powder, Milk powder, Watermelon powder

How to cite this article : Arya, Asha, Doke, Anuradha, Bhalerao, Jaishree G. and Shinde, Rupali S. (2017). Development of value added fruit jams. Food Sci. Res. J., 8(1): 1-6, DOI : 10.15740/HAS/FSRJ/8.1/1-6. 